\title{
Immunoexpression of P63 and SOX2 in triple-negative breast
}

\section{cancers, Indonesia [version 1; peer review: 2 approved with}

\section{reservations]}

\author{
Reno K Kamarlis ${ }^{1,2}$, Muhammad ND Lubis 3 , Bethy S Hernowo 4 , \\ Harapan Harapan (D) 5 , Azmi S Kar6 \\ 1Department of Pathology Anatomy, Dr. Zainoel Abidin General Hospital, Banda Aceh, Indonesia \\ ${ }^{2}$ Department of Pathology Anatomy, School of Medicine, Syiah Kuala University, Banda Aceh, Indonesia \\ ${ }^{3}$ Department of Pathology Anatomy, Medical Faculty, Sumatera Utara University, Medan, Indonesia \\ ${ }^{4}$ Department of Pathology Anatomy, Medical Faculty, Padjajaran University, Bandung, Indonesia \\ ${ }^{5}$ Medical Research Unit, School of Medicine, Syiah Kuala University, Banda Aceh, Indonesia \\ ${ }^{6}$ Department of Internal Medicine, Medical Faculty, Sumatera Utara University, Medan, Indonesia
}

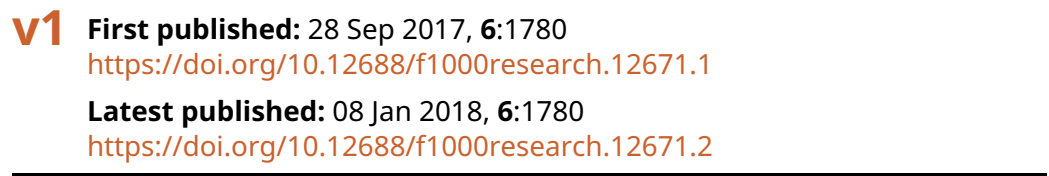

\section{Abstract}

Background: Using immunohistochemical stains to target specific breast cancer markers has become indispensable for evaluation of small diagnostic tissue specimens, and therefore novel marker cocktails for specific breast cancers are required. This study was conducted to assess the immunoexpression of P63 and SOX2 in triple negative breast cancer (TNBC), and to evaluate the predictive diagnostic value of these markers for specific types of TNBC. Methods: Histological slides and paraffin blocks of TNBC cases were collected from Dr. Hasan Sadikin Hospital, Bandung, Indonesia from 5-years period (2011-2015). Each histological slide was subjected to immunohistochemical staining for P63 (nucleus and cytoplasm) and SOX2 (nucleus), with specific primer antibodies. Immunoexpression of P63 and SOX2 was evaluated using immunoreactivity scoring. Associations between P63 and SOX2 immunoexpression and TNBC types were assessed using Mann Whitney tests. In addition, the predictive diagnostic values of these markers were assessed. Results: Forty TNBC histological slides were included, and 23 (57.5\%) were Basal-like type TNBC and 17 (42.5\%) were Non basal-like type TNBC. Immunoexpression of P63 nucleus and SOX2 was not different between types of TNBC. However, immunoexpression of P63 in the cytoplasm in Basal-like type TNBC was significantly higher than in Non basal-like type TNBC $(p=0.021)$. Predictor diagnostic value analysis suggested that immunoexpression of P63 in cytoplasm had $56.5 \%$ sensitivity and $70.6 \%$ specificity for diagnosing Basal-like type TNBC, with area under curve of 0.64 .

Conclusions: Immunoexpression of P63 in the cytoplasm has a

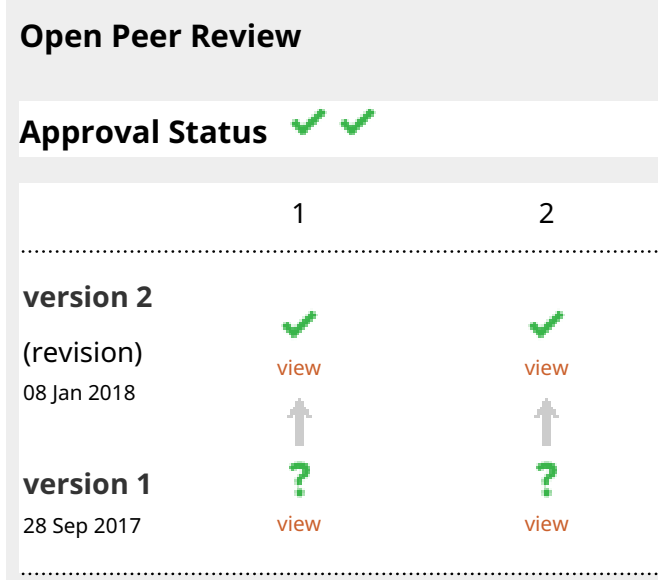

1. Irianiwati Widodo, Gadjah Mada University, Yogyakarta, Indonesia

2. Diah Rini Handjari, University of Indonesia, Jakarta, Indonesia

Any reports and responses or comments on the article can be found at the end of the article. 
relatively weak diagnostic value to discriminate Basal-like and Non basal-like types of TNBC.

\section{Keywords}

breast cancer, breast cancer marker, P63, SOX2, triple negative breast cancers

Corresponding authors: Reno K Kamarlis (reno.sppa@yahoo.com), Harapan Harapan (harapan@unsyiah.ac.id)

Author roles: Kamarlis RK: Conceptualization, Data Curation, Formal Analysis, Funding Acquisition, Methodology, Resources, Validation, Visualization; Lubis MN: Conceptualization, Data Curation, Investigation, Methodology, Supervision, Validation; Hernowo BS:

Conceptualization, Data Curation, Funding Acquisition, Investigation, Methodology, Resources, Supervision, Validation; Harapan H: Conceptualization, Data Curation, Formal Analysis, Validation, Visualization, Writing - Original Draft Preparation, Writing - Review \& Editing; Kar AS: Conceptualization, Data Curation, Funding Acquisition, Resources, Supervision, Validation

Competing interests: No competing interests were disclosed.

Grant information: The author(s) declared that no grants were involved in supporting this work.

Copyright: @ 2017 Kamarlis RK et al. This is an open access article distributed under the terms of the Creative Commons Attribution License, which permits unrestricted use, distribution, and reproduction in any medium, provided the original work is properly cited. Data associated with the article are available under the terms of the Creative Commons Zero "No rights reserved" data waiver (CC0 1.0 Public domain dedication).

How to cite this article: Kamarlis RK, Lubis MN, Hernowo BS et al. Immunoexpression of P63 and SOX2 in triple-negative breast cancers, Indonesia [version 1; peer review: 2 approved with reservations] F1000Research 2017, 6:1780 https://doi.org/10.12688/f1000research.12671.1

First published: 28 Sep 2017, 6:1780 https://doi.org/10.12688/f1000research.12671.1 


\section{Introduction}

Breast cancer, accounting for $25 \%$ of all cancer cases and $15 \%$ of all cancer deaths among females, is the most frequently diagnosed cancer among female worldwide ${ }^{1,2}$. In 2012, it was estimated that there were 1.7 million breast cancer cases with more than half million deaths. Between 1980s and 1990s, the incidence of breast cancer increased significantly, approximately by $30 \%$ in developed countries $^{3}$ and currently it has been also rising in many developing countries $^{2}$. In Asia, 639,824 breast cancer cases and 228,926 deaths were recorded in 2012, from which 48,998 cases and 19,750 deaths occurred in Indonesia ${ }^{4}$.

Advanced screening and diagnosis methods for breast cancer such as mammograms, ultrasound, magnetic resonance imaging and fine-needle aspiration, have allowed for detection of small lesions at the early stage. Identifying breast cancer at the early stage will increase the potential for curative treatment and therefore increases the survival rate ${ }^{5-8}$. However, smaller lesions are more challenging to diagnose. Therefore, it is essential to use an advanced immunohistochemical approach for evaluation of smaller tissue specimens that target more specific markers 9 .

A previous study using a MCF7 breast cancer cell line to produce MCF7-derived tumour xenografts found that P63 and SOX2 immunostainings were two potential markers for breast cancer ${ }^{10}$. P63, involved in cellular differentiation, is a homolog of tumour protein P53 and in normal breast ducts and lobules it is expressed frequently in the nuclei of myoepithelial cells ${ }^{11}$. Mutation of the p53 gene results in a very high risk of breast cancer ${ }^{12}$. A study revealed that the total percentage of P63-positive cells was related to marked nuclear pleomorphism and the intensity of P63 staining was associated with syncytial growth pattern in triple-negative breast cancer $(\mathrm{TNBC})^{13}$. In addition, data also reveals that $p 63$ gene expression in breast cancer could be used as a specific marker of metaplastic carcinoma ${ }^{11}$, and P63 immunohistochemical staining could improve diagnostic accuracy of breast cancer even in small tissue specimens ${ }^{14}$.

SOX2 is a transcription factor belonging to the SOX family and functions as an activator or suppressor of gene transcription ${ }^{15,16}$. Data shows that SOX2 promotes cellular proliferation of breast tissue $^{17}$ and regulates self-renewal in cancer stem cells ${ }^{18}$. The scientific evidence reveals that SOX2 acts as an oncogene in epithelial cancers ${ }^{16}$ and in the breast, a study found that silencing of sox 2 gene was associated with reduction of the size of the cancer stem cells and restoration of tamoxifen sensitivity ${ }^{19}$. All together, these data indicate that P63 and SOX2 have pivotal role in breast cancer and therefore are potential to be used as specific biomarkers. This study was conducted to assess the immunoexpression of P63 and SOX2 in TNBC cases in order to provide insight regarding their potential diagnostic value (single or in combination) to differentiate TNBC types.

\section{Methods}

Study setting and histological slides

A cross-sectional study to assess the immunoexpression of P63 and SOX2 in TNBC cases (negative expression of estrogen and progesterone receptors and c-erbB2) was conducted. Histological slides of TNBC and their paraffin blocks, tested between the $1^{\text {st }}$ of January 2011 and $31^{\text {st }}$ of December 2015, were collected from the Pathology Anatomy Laboratory, Dr. Hasan Sadikin Hospital, Bandung, Indonesia. Each histological slide was examined by two certified pathologists. To classify the type of TNBC morphology, between Basal-like type TNBC and Non basal-like type TNBC, cytokeratin 5/6 (CK 5/6) immunohistochemical staining was carried out on all TNBC histological slides. Concurrently, the immunoexpression of P63 and SOX2 was measured using immunohistochemical stains with specific primer antibodies. The protocol of this study was approved by the Health Research Ethical committee of Sumatera Utara University (approval 103/KOMET/FK USU/2015) and the usage of histological specimens was approved by the Pathology Anatomy Laboratory of Dr. Hasan Sadikin Hospital (LB.02.01/ B29/239/X/2015).

\section{Immunohistochemistry}

Forty archival paraffin blocks from TNBC cases were subjected to immunohistochemical staining to assess the immunoexpression of CK 5/6, P63 and SOX2. Briefly, $4 \mu \mathrm{m}$ sections of each paraffin block were prepared using standard procedure ${ }^{20}$. Immunohistochemical staining was conducted using primary antibodies as follows: anti-CK5/6 monoclonal antibody (Biocare Medical, Concord, CA, USA), anti-P63 monoclonal antibody (Biocare Medical, Concord, CA, USA) and anti-SOX2 monoclonal antibody (Abcam, Cambridge, UK). Starr Trek Universal HRP Detection (Biocare Medical, Concord, CA, USA) was used as second antibody. A chromogen 3,3'-diaminobenzidine (DAB) (Biocare Medical, Concord, CA, USA) was used to develop the colour. For each experiment, appropriate controls were used.

Immunoexpression of $\mathrm{CK} 5 / 6$ was interpreted as positive or negative, in which positive CK 5/6 indicates Basal-like type TNBC while negative CK 5/6 indicates Non basal-like type TNBC. Immunoexpression of P63 and SOX2 was evaluated using an immunoreactivity scoring system that had been published elsewhere with modification ${ }^{13}$. Staining intensity was scored as follows: 1 (no staining), 2 (weak staining), 3 (moderate staining) and 4 (strong staining). The percentage of positively stained tumour cells was assessed as a proportion of the total number of tumour cells present in the section as follows: $1(<20 \%), 2$ $(\geq 20-50 \%), 3(>50-80 \%)$ and $4(>80 \%)$.

Immunoreactivity score was calculated by multiplying staining intensity and the percentage of positivity, and the score therefore ranged from 1 to 16 . The immunoreactive score was then divided into low $(\leq 5)$, moderate $(\geq 6-10)$ and high $(\geq 11-16)$. Immunoexpression of P63 was measured both in cytoplasm and nucleus while SOX2 immunoexpression was measured in nucleus only.

\section{Statistical analysis}

Normality of the data was assessed using the Shapiro-Wilk test and therefore the analysis tests chosen based on the normality of the data. The correlations between immunoexpression of P63 (cytoplasm and nucleus) and SOX2 were assessed using 
Pearson correlation and Spearman correlation, respectively. The associations of P63 and SOX2 immunoexpression and type of TNBC were assessed using Mann Whitney test. The predictive diagnostic values of P63 cytoplasm for diagnosing Basal-like type TNBC were estimated using several immunoreactivity score cut-off points. Receiver operating characteristic curve (ROC) was plotted and area under the ROC curves (AUC) was estimated. For all analyses, estimates were considered statistically significant for two-tailed values of $p<0.05$. All analyses were conducted using Statistical Package for the Social Sciences software (SPSS for Windows, Version 16, Chicago, IL).

\section{Results}

\section{Clinicopathology and classification of TNBC}

The histopathology of the TNBC samples used in this study is described in Table 1. Approximately $45 \%$ of the samples were classified as metaplastic carcinomas. In addition, immunohistochemical staining for $\mathrm{CK} 5 / 6$ revealed that $23(57.5 \%)$ of samples were Basal-like type TNBC and while 17 (42.5\%) samples were Non basal-like type TNBC.

\section{Immunoreactivity score of P63 and SOX2}

Immunoexpression of P63 and SOX2 in samples, categorized by immunoreactivity score, are presented in Table 2. For both types of TNBC (basal and non basal-like type), all immunoreactivity scores for P63 in the nucleus were classified as low grade, while $11(27.5 \%)$ and $7(17.5 \%)$ samples were classified as moderate

\section{Table 1. Histopathology types of TNBC samples used in this study $(\mathrm{N}=40)$.}

\begin{tabular}{|l|c|}
\hline Type of histopathology & $\boldsymbol{n}(\%)$ \\
\hline Metaplastic carcinoma, spindle cells component & $10(25.0)$ \\
\hline Metaplastic carcinoma, producing mucin & $3(7.5)$ \\
\hline Metaplastic carcinoma, liposarcoma component & $2(5.0)$ \\
\hline Metaplastic carcinoma, squamous cell & $1(2.5)$ \\
\hline Metaplastic carcinoma, matrix hyaline & $1(2.5)$ \\
\hline Medullary carcinoma & $13(32.5)$ \\
\hline Micropapillary carcinoma & $1(2.5)$ \\
\hline Invasive ductal carcinoma grade 3 & $6(15.0)$ \\
\hline Invasive lobular carcinoma grade 3 & $2(5.0)$ \\
\hline $\begin{array}{l}\text { Invasive ductal carcinoma + invasive lobular } \\
\text { carcinoma (mixed) }\end{array}$ & $1(2.5)$ \\
\hline
\end{tabular}

Table 2. Immunoreactivity score of P63 and SOX2 in TNBC.

\begin{tabular}{|l|l|l|l|}
\hline Grade & $\begin{array}{l}\text { P63 cytoplasm, } \\
\boldsymbol{n}(\mathbf{\%})\end{array}$ & $\begin{array}{l}\text { P63 nucleus, } \\
\boldsymbol{n}(\mathbf{\%})\end{array}$ & $\begin{array}{l}\text { SOX2, } \\
\boldsymbol{n}(\%)\end{array}$ \\
\hline Low $(\leq 5)$ & $22(55.0)$ & $40(100.0)$ & $19(47.5)$ \\
\hline Moderate $(\geq 6-10)$ & $11(27.5)$ & $0(0.0)$ & $12(30.0)$ \\
\hline High $(\geq 11-16)$ & $7(17.5)$ & $0(0.0)$ & $9(22.5)$ \\
\hline
\end{tabular}

and high grade, respectively for the P63 in the cytoplasm. The immunoreactivity grade for SOX2 was similar to P63 in the cytoplasm, and therefore correlation analyses were conducted.

\section{Correlation between immunoexpression of P63 and SOX2}

There was a strong negative correlation between immunoexpression of P63 in the cytoplasm and immunoexpression of SOX2 in the nucleus in metaplastic carcinoma (a sub-type of TNBC basal-like type) ( $\mathrm{r}=-0.73, p=0.013$ ) (Table 3$)$. In addition, linear regression showed a relatively strong correlation between P63 cytoplasm and SOX2 immunoexpression in metaplastic carcinoma $(\mathrm{r}=0.49, p=0.012)$. There was no significant correlation between P63 cytoplasm and SOX2 immunoexpression in Non basal-like type TNBC, and no significant correlation between P63 nucleus and SOX2 immunoexpression either in Basal-like type or Non basal-like type of TNBC.

\section{Immunoexpression of P63 and SOX2 in Basal-like and} Non basal-like type of TNBC

Immunoexpression of P63 cytoplasm, P63 nucleus and SOX2 in Basal-like and Non Basal-like TNBC is shown in Table 4. The data indicates that the immunoexpression of P63 cytoplasm in Basal-like type TNBC was significantly higher compared to Non basal-like type TNBC $(p=0.021)$. Immunoexpression of P63 nucleus and SOX2 was not different between Basal-like and Non basal-like types of TNBC, with $p$-values of $p=0.27$ and $p=0.17$, respectively.

Predictor diagnostic value of P63 in the cytoplasm for diagnosing Basal like type TNBC

As mentioned above, immunoexpression of P63 in the cytoplasm was the only marker that was significantly different between TNBC types. Therefore, immunoreactivity score of P63 cytoplasm was further analysed to determine its ability to predict Basallike type TNBC. Table 5 shows the predictive values of P63 in the

Table 3. Correlation between immunoexpression of P63 cytoplasm and SOX2 in Basal-like type TNBC.

\begin{tabular}{|c|c|c|c|c|c|}
\hline \multirow{2}{*}{$\begin{array}{l}\text { TNBC basal-like } \\
\text { type }\end{array}$} & \multirow{2}{*}{$n$} & \multirow{2}{*}{$\begin{array}{l}\text { P63 } \\
\text { Mean ( } \pm S D)\end{array}$} & sox2 & \multirow[t]{2}{*}{$\mathbf{r}$} & \multirow[t]{2}{*}{$p$} \\
\hline & & & Mean ( $( \pm S D)$ & & \\
\hline $\begin{array}{l}\text { Invasive ductal } \\
\text { carcinoma }\end{array}$ & 2 & $5.50(3,54)$ & $5.00(5.66)$ & - & - \\
\hline $\begin{array}{l}\text { Invasive ductal } \\
\text { carcinoma and } \\
\text { invasive lobular } \\
\text { carcinoma }\end{array}$ & 1 & $16.00(0.00)$ & $9.00(0.00)$ & - & - \\
\hline $\begin{array}{l}\text { Invasive lobular } \\
\text { carcinoma }\end{array}$ & 1 & $8.00(0.00)$ & $1.00(0.00)$ & - & - \\
\hline $\begin{array}{l}\text { Invasive } \\
\text { micropapillary } \\
\text { carcinoma }\end{array}$ & 1 & $12.00(0.00)$ & $16.00(0.00)$ & - & - \\
\hline $\begin{array}{l}\text { Medullary } \\
\text { carcinoma }\end{array}$ & 6 & $5.50(4.76)$ & $8.00(5.48)$ & 0.64 & 0.172 \\
\hline $\begin{array}{l}\text { Metaplastic } \\
\text { carcinoma }\end{array}$ & 12 & 6.67 (4.68) & $6.00(3.77)$ & -0.73 & $0.013^{\star}$ \\
\hline
\end{tabular}

*Significant at 0.05 
Table 4. Immunoexpression of P63 and SOX2 in Basal-like type TNBC and Non basal-like type TNBC.

\begin{tabular}{|l|l|l|l|c|}
\hline Marker & TNBC type & $\boldsymbol{n}$ & $\begin{array}{l}\text { Immunoreactivity } \\
\text { score Mean (ISD) }\end{array}$ & $\boldsymbol{p}$ \\
\hline P63 cytoplasm & Basal-like & 23 & $6.96(4,73)$ & $0.021^{*}$ \\
\cline { 2 - 5 } & Non basal-like & 17 & $3.76(4,16)$ & \\
\hline P63 nucleus & Basal-like & 23 & $1.22(0,52)$ & 0.273 \\
\cline { 2 - 5 } & Non basal-like & 17 & $1.06(0,24)$ & \\
\hline SOX2 & Basal-like & 23 & $6.78(4,69)$ & 0.172 \\
\hline & Non basal-like & 17 & $4.82(3,61)$ & \\
\hline
\end{tabular}

*Significant at 0.05 cytoplasm for determining Basal-like type TNBC, using seven immunoreactivity score cut-off values from 3 to 9 . It shows that P63 has relatively weak diagnostic value in diagnosing Basallike type TNBC. The highest sensitivity was achieved at immunoreactivity score 3 , while specificity was increasing with a higher immunoreactivity score.

Using the average score of P63 cytoplasm immunoexpression for Basal-like type TNBC in this study, 5.6 or 6 , the sensitivity and specificity of P63 cytoplasm immunoreactivity score to predict Basal-like type TNBC was $56.5 \%$ and $72.6 \%$, respectively with area under curve 0.64 . The receiver operating curve of predictive diagnostic value of P63 cytoplasm for determining Basal-like type TNBC is plotted in Figure 1.

Table 5. Predictor diagnostic value of P63 in the cytoplasm for diagnosing Basallike type TNBC.

\begin{tabular}{|l|l|l|l|l|l|l|l|}
\hline & \multicolumn{6}{|c|}{ Cut-off of P63 cytoplasm immunoreactivity score } \\
\hline & $\mathbf{3}$ & $\mathbf{4}$ & $\mathbf{5}$ & $\mathbf{6}$ & $\mathbf{7}$ & $\mathbf{8}$ & $\mathbf{9}$ \\
\hline Sensitivity (\%) & 78.3 & 73.9 & 56.5 & 56.5 & 52.2 & 52.2 & 30.4 \\
\hline Specificity (\%) & 58.8 & 58.8 & 70.6 & 70.6 & 82.4 & 82.4 & 88.2 \\
\hline Positive predictive value (\%) & 72.0 & 70.8 & 72.2 & 72.2 & 80.0 & 80.0 & 77.8 \\
\hline Negative predictive value (\%) & 66.7 & 62.5 & 54.5 & 54.5 & 56.0 & 56.0 & 48.4 \\
\hline Positive likelihood ratio (\%) & 190.1 & 179.5 & 192.2 & 192.2 & 295.7 & 295.7 & 258.7 \\
\hline Negative likelihood ratio (\%) & 37.0 & 44.3 & 61.6 & 61.6 & 58.1 & 58.1 & 78.8 \\
\hline Accuracy (\%) & 70.0 & 67.5 & 62.5 & 62.5 & 65.0 & 65.0 & 55.0 \\
\hline
\end{tabular}

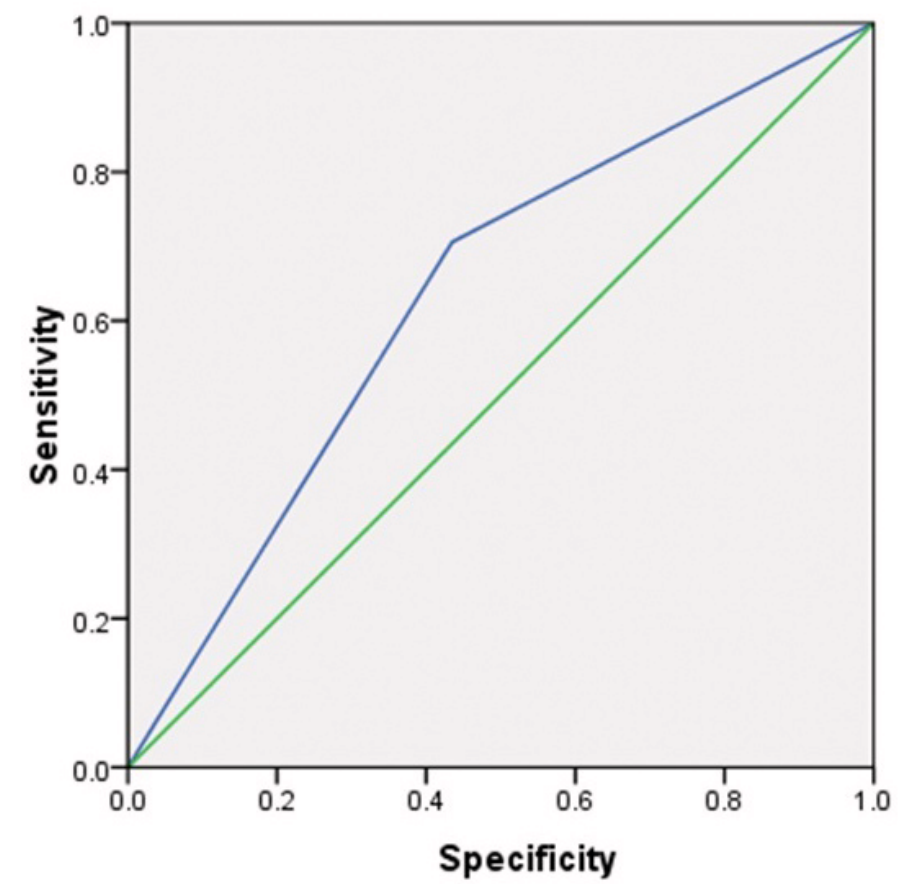

Figure 1. Receiver operating curve of P63 cytoplasm immunoexpression for determining TNBC basal-like type. 
Dataset 1. Immunoexpression and immunoreactivity scores of P63, SOX2 and CK 5/6 in the forty specimens that were analysed

http://dx.doi.org/10.5256/f1000research.12671.d179131

\section{Discussion}

To the best of our knowledge, this is the first study conducted to assess the immunoexpression of P63 and SOX2 in TNBC cases in Indonesia. Some studies have been conducted to assess the predictive values of P63 as specific marker for breast cancer ${ }^{11,21}$. In addition, the idea of utilization of a cocktail of specific markers has been proposed previously to provide higher sensitivity and specificity for diagnosing specific breast cancers ${ }^{9,13,22}$. However, none of the previous studies had been conducted to assess the diagnostic value of immunoexpression of P63 and SOX2 in combination. This study, at the beginning, sought to assess predictive value of combination both of those markers for specific type of TNBC. However, we found that there was no difference in immunoexpression of SOX2 between Basal-like type TNBC and Non basal-like type TNBC. Nevertheless, we found that immunoexpression of P63 cytoplasm, but not P63 nucleus, was higher in Basal-like type TNBC compared to Non basal-like type TNBC.

P63 is highly expressed in embryonic ectoderm and in the nuclei of basal regenerative cell of many epithelial tissues ${ }^{23}$. P63 is expressed selectively in basal mammary epithelial cells and its expression is increased during mammary gland maturation ${ }^{24}$. P63 has been proposed as a breast cancer marker for a long time, but with conflicting results. A study demonstrated that immunoexpression of P63 was associated with breast cancers, for example the metaplastic carcinoma type of breast cancer $^{11}$, but there was no difference in immunoexpression of P63 between medullary breast carcinomas and atypical medullary breast carcinomas of $\mathrm{TNBC}^{21}$. In our study, we found that the sensitivity and specificity of P63 cytoplasm immunoexpression to diagnose Basal-like type TNBC was $56.5 \%$ and $72.6 \%$, respectively, with area under curve of 0.64 . This sensitivity and specificity seems higher compared to a previous study, with $14 \%$ and $94 \%$, respectively in determining a Basal-like type in infiltrative ductal carcinomas (TNBC) ${ }^{13}$. All together, these data indicate a weak predictive value of P63 immunoexpression as marker for Basal-like type TNBC. However, a study found that P63 is a specific marker for metaplastic carcinomas of the breast (a sub-type of Basal-like type TNBC) $)^{11}$. In our study, we could not assess the predictive value of P63 cytoplasm immunoexpression for determining metaplastic carcinomas, due to the small sample size (see Table 3).
We found that SOX2 immunoexpression grade was classified as moderate and high grade in 55\% of TNBC cases (Table 2,) and it has been indicated previously that SOX2 has strong roles in promoting breast cancers ${ }^{17-19,25}$. However, there was no different in immunoexpression between Basal-like type TNBC and Non basal-like type TNBC. This result indicates that SOX2 expression is not different amongst TNBC types. This finding was in line with a previous study that indicated that $\mathrm{SOX} 2$ was expressed across different breast cancer subtypes ${ }^{26}$. A study found that SOX2 antibody in the sera was is higher in patients with breast cancer compared to healthy women and therefore it could be used to discriminate between breast cancer patients and healthy controls ${ }^{27}$. In addition, a meta-analysis found that SOX2 expression was associated with tumor size, histological grade, the aggressiveness and lymph node metastasis in TNBC patients ${ }^{28}$. All together, these results indicate that there was a possibility SOX2 expression could be used for diagnosing breast cancers, but there was no difference in expression amongst breast cancer types, and therefore it could not be used as specific marker for differentiating TNBC types.

There are some limitations to this study. The sample size was relatively small, and therefore some analyses could not be conducted. In addition, the diagnostic specimens were collected from different procedures such as from biopsy, mastectomy or lumpectomy, and this might influence the immunoexpression of the markers.

\section{Conclusions}

Immunoexpression of P63 cytoplasm is higher among Basal-like type TNBC compared to Non basal-like type TNBC. However, the predictive diagnostic value of $\mathrm{P} 63$ immunoexpression in the cytoplasm for Basal-like type TNBC is relatively low, with $56.5 \%$ sensitivity and $72.6 \%$ specificity.

\section{Data availability}

Dataset 1: Immunoexpression and immunoreactivity scores of P63, SOX2 and CK 5/6 in the forty specimens that were analysed. DOI, 10.5256/f1000research.12671.d17913129

\section{Competing interests}

No competing interests were disclosed.

\section{Grant information}

The author(s) declared that no grants were involved in supporting this work.
1. Key TJ, Verkasalo PK, Banks E: Epidemiology of breast cancer. Lancet Oncol. 2001; 2(3): 133-140.

PubMed Abstract | Publisher Full Text

2. Torre LA, Bray F, Siegel RL, et al: Global Cancer Statistics, 2012. CA Cancer J Clin. 2015; 65(2): 87-108.

PubMed Abstract | Publisher Full Text
3. Althuis MD, Dozier JM, Anderson WF, et al.: Global trends in breast cancer incidence and mortality 1973-1997. Int J Epidemiol. 2005; 34(2): 405-412. PubMed Abstract | Publisher Full Text

4. Ghoncheh M, Momenimovahed Z, Salehiniya H: Epidemiology, Incidence and Mortality of Breast Cancer in Asia. Asian Pac J Cancer Prev. 2016; 17(S3): 47-52. PubMed Abstract | Publisher Full Text 
5. AlHW: Breast cancer survival by size and nodal status in Australia. In: Registries NBCCAAoC, ed. Cancer series no. 39. Canberra: AlHW; 2007. Reference Source

6. Allemani C, Minicozzi P, Berrino F, et al.: Predictions of survival up to 10 years after diagnosis for European women with breast cancer in 2000-2002. Int $J$ Cancer. 2013; 132(10): 2404-2412. PubMed Abstract | Publisher Full Text

7. Allemani $\mathrm{C}$, Weir $\mathrm{HK}$, Carreira $\mathrm{H}$, et al:: Global surveillance of cancer survival 1995-2009: analysis of individual data for $25,676,887$ patients from 279 population-based registries in 67 countries (CONCORD-2). Lancet. 2015; 385(9972): 977-1010

PubMed Abstract | Publisher Full Text | Free Full Text

8. Naroda S, Iqbala J, Miller AB: Why have breast cancer mortality rates declined? J Cancer Policy. 2015; 5: 8-17. Publisher Full Text

9. Reisenbichler ES, Ross JR, Hameed O: The clinical use of a P63/cytokeratin7/18/ cytokeratin5/14 antibody cocktail in diagnostic breast pathology. Ann Diagn Pathol. 2014; 18(6): 313-318.

PubMed Abstract | Publisher Full Text

10. Liu Y, Coates PJ, Nenutil R, et al: Lack of correlation between markers of breast cancer initiating cells. Breast Cancer Research. 2010; 12(Suppl 1): P38. Publisher Full Text

11. Koker MM, Kleer CG: $\mathbf{p 6 3}$ expression in breast cancer: a highly sensitive and specific marker of metaplastic carcinoma. Am J Surg Pathol. 2004; 28(11): 1506-1512.

PubMed Abstract | Publisher Full Text

12. Assi HA, Khoury KE, Dbouk H, et al:: Epidemiology and prognosis of breast cancer in young women. $J$ Thorac Dis. 2013; 5 Suppl 1: S2-8.

PubMed Abstract | Publisher Full Text | Free Full Text

13. Thike AA, Cheok PY, Jara-Lazaro AR, et al:: Triple-negative breast cancer: clinicopathological characteristics and relationship with basal-like breast cancer. Mod Pathol. 2010; 23(1): 123-133. PubMed Abstract | Publisher Full Text

14. Harton AM, Wang HH, Schnitt SJ, et al.: p63 Immunocytochemistry improves accuracy of diagnosis with fine-needle aspiration of the breast. Am J Clin Pathol. 2007; 128(1): 80-85.

PubMed Abstract | Publisher Full Text

15. Weina $\mathrm{K}$, Utikal $\mathrm{J}$ : SOX2 and cancer: current research and its implications in the clinic. Clin Trans/ Med. 2014; 3: 19 PubMed Abstract | Publisher Full Text | Free Full Text

16. Sarkar A, Hochedlinger $\mathrm{K}$ : The sox family of transcription factors: versatile regulators of stem and progenitor cell fate. Cell Stem Cell. 2013; 12(1): 15-30. PubMed Abstract | Publisher Full Text | Free Full Text

17. Stolzenburg S, Rots MG, Beltran AS, et al:: Targeted silencing of the oncogenic transcription factor SOX2 in breast cancer. Nucleic Acids Res. 2012; 40(14):
$6725-6740$

PubMed Abstract | Publisher Full Text | Free Full Text

18. Leis O, Eguiara A, Lopez-Arribillaga $\mathrm{E}$, et al:: Sox2 expression in breast tumours and activation in breast cancer stem cells. Oncogene. 2012; 31(11): 1354-1365. PubMed Abstract | Publisher Full Text

19. Piva M, Domenici G, Iriondo O, et al:: Sox2 promotes tamoxifen resistance in breast cancer cells. EMBO Mol Med. 2014; 6(1): 66-79. PubMed Abstract | Publisher Full Text | Free Full Text

20. Anderson G, Bancroft J: Tissue processing and microtomy. In: Bancroft JG, M., ed. Theory and practiceal of histological techniques 5th Edition. Edinburgh Churchill Livingstone; 2002; 109-123.

21. Matkovic B, Juretic A, Separovic V, et al:: Immunohistochemical analysis of ER, PR, HER-2, CK 5/6, p63 and EGFR antigen expression in medullary breast cancer. Tumori. 2008; 94(6): 838-844.

PubMed Abstract

22. Tacha DE, Bloom K, Kyshtoobayava A, et al:: A double immunostaining technique with a cocktail CK5, CK14, p63, CK7 and CK18 distinguishes between hyperplasia of the usual type, atypical hyperplasia, microinvasive and basal phenotype breast cancers. Modern Pathology. 2009; 22: 388a.

23. Westfall MD, Pietenpol JA: p63: Molecular complexity in development and cancer. Carcinogenesis. 2004; 25(6): 857-864. PubMed Abstract | Publisher Full Text

24. Forster N, Saladi SV, van Bragt M, et al:: Basal cell signaling by p63 controls luminal progenitor function and lactation via NRG1. Dev Cell. 2014; 28(2): $147-160$.

PubMed Abstract | Publisher Full Text | Free Full Text

25. Liu K, Xie F, Gao A, et al:: SoX2 regulates multiple malignant processes of breast cancer development through the SOX2/miR-181a-5p, miR-30e-5p/TUSC3 axis. Mol Cancer. 2017; 16(1): 62.

PubMed Abstract | Publisher Full Text | Free Full Text

26. Lengerke $\mathrm{C}$, Fehm $\mathrm{T}$, Kurth R, et al:: Expression of the embryonic stem cell marker SOX2 in early-stage breast carcinoma. BMC Cancer. 2011; 11: 42. PubMed Abstract | Publisher Full Text | Free Full Text

27. Sun $Y$, Zhang $R$, Wang MJ, et al:: SOX2 autoantibodies as noninvasive serum biomarker for breast carcinoma. Cancer Epidemiol Biomarkers Prev. 2012; 21(11): 2043-2047. PubMed Abstract | Publisher Full Text

28. Zheng Y, Qin B, Li F, et al:: Clinicopathological significance of Sox2 expression in patients with breast cancer: a meta-analysis. Int J Clin Exp Med. 2015; 8(12) 22382-22392.

PubMed Abstract | Free Full Text

29. Harapan H, Reno KK, Muhammad NDL, et al.: Dataset 1 in: Immunoexpression of P63 and SOX2 in triple-negative breast cancers, Indonesia. F100OResearch. 2017.

Data Source 


\section{Open Peer Review}

\section{Current Peer Review Status: ? ?}

\section{Version 1}

Reviewer Report 20 October 2017

https://doi.org/10.5256/f1000research.13722.r26782

(C) 2017 Rini Handjari D. This is an open access peer review report distributed under the terms of the Creative Commons Attribution License, which permits unrestricted use, distribution, and reproduction in any medium, provided the original work is properly cited.

\section{Diah Rini Handjari}

University of Indonesia, Jakarta, Indonesia

I. - In introduction there is only little information regarding of nuclear expression of p63.

- It doesn't mention about cytoplasmic p63 expression.

What is significance function of p63 in tumor progression or disease progression?

It written in result and analysis.

- In introduction you haven't discussed yet about the incidence of triple negative breast cancer in the worldwide, Asia or Indonesia?

II. In the methods, to classify TNBC morphology into Basal like and non Basal like, based on only, antibody (CK 5/6) but you didn't perform EGFR staining. Which is one of the marker of TNBC.

- Is there any reference about the scoring of intensity and the percentage of positivity of expression of $\mathrm{p63}$ ?

- Is there any reference about imunoreactive score?

III. In discussion, there is also no information about cytoplasmic p63 and its role in disease progression.

- Researcher only stated that cytoplasmic p63 expression has predictive value to classify breast cancer into TNBC and there is no comparison of p63 expression sensitivity and specificity with other TNBC marker as like CK 5/6 and EGFR which has been routinely used.

Is the work clearly and accurately presented and does it cite the current literature? Partly

Is the study design appropriate and is the work technically sound? Yes

Are sufficient details of methods and analysis provided to allow replication by others? Yes 


\section{If applicable, is the statistical analysis and its interpretation appropriate?}

I cannot comment. A qualified statistician is required.

Are all the source data underlying the results available to ensure full reproducibility? Partly

Are the conclusions drawn adequately supported by the results?

Partly

Competing Interests: No competing interests were disclosed.

Reviewer Expertise: Pathologist with major interest in colorectal cancer

I confirm that I have read this submission and believe that I have an appropriate level of expertise to confirm that it is of an acceptable scientific standard, however I have significant reservations, as outlined above.

Author Response 25 Nov 2017

Harapan Harapan, Syiah Kuala University, Banda Aceh, Indonesia

Thank you for comments and suggestion. We have deleted some sentences related to the general introduction of breast cancer and added specific information related to TNBC. We would like to confirm that predictive diagnostic analysis in this study was conducted using qualified statistician. There is no evidence to support the importance of the negative correlation between immunoexpression of P63 cytoplasm and immunoexpression SOX2 nucleus in metaplastic carcinoma, and therefore we are unable to discuss this finding in depth. In conclusion section, we have added some additional principal finding as suggested by the reviewer.

Competing Interests: There is no competing interest in this study.

Author Response 25 Nov 2017

Harapan Harapan, Syiah Kuala University, Banda Aceh, Indonesia

Thank you for comments and suggestion. We have deleted some sentences related to the general introduction of breast cancer and added specific information related to TNBC. In the revised manuscript, the data of the incidence from global, Southeast Asian countries and Indonesia are included.

In our study, we used the histological paraffin blocks that have been confirmed as TNBC previously by testing ER, PR and HER2. To differentiate Basal like and non Basal like, either CK $5 / 6$ or EGFR staining could be used with no significant different sensitivity and specificity (Livasy et al., 2006; Nielsen et al., 2004). In this study, CK 5/6 was employed to differentiate TNB into Basal like and non Basal like and this procedure was conducted during the study. This method is established method to define basal phenotype (Sasa et al., 2008; Rakha et al., 2007). 
In our study, we used the histological paraffin blocks that have been confirmed as TNBC previously by testing ER, PR and HER2. To differentiate Basal like and non Basal like, either CK 5/6 or EGFR staining could be used with no significant different sensitivity and specificity (Livasy et al., 2006; Nielsen et al., 2004). In this study, CK 5/6 was employed to differentiate TNB into Basal like and non Basal like and this procedure was conducted during the study. This method is established method to define basal phenotype (Sasa et al., 2008; Rakha et al., 2007). CK 5/6 and EGFR.

As mentioned Immunohistochemistry Section, the principle of the scoring system for immunoexpression of P63 and SOX2 used in this study was have been elsewhere with modification (Thike et al., 2010). In detailed: Staining intensity was scored as follows: 1 (no staining), 2 (weak staining), 3 (moderate staining) and 4 (strong staining). The percentage of positively stained tumour cells was assessed as a proportion of the total number of tumour cells present in the section as follows: $1(<20 \%), 2$ ( $\geq 20-50 \%), 3(>50-80 \%)$ and $4(>80 \%)$. Then from staining intensity and percentage of positively stained cells, we created immunoreactivity score by multiplying staining intensity and the percentage of positivity. The score, therefore, ranged from 1 to 16 (divided into low $(\leq 5)$, moderate ( $\geq 6-10)$ and high ( $\geq 11-16)$. However, specifications for staining intensity and the percentage of positivity used in this study are the standard system used by Pathology Anatomy Laboratory of Dr. Hasan Sadikin Hospital Bandung since 1990. These score systems are also adopted in some breast cancer diagnostic centres in Indonesia.

Immunoreactive score system used in this study have been published elsewhere (Thike et al. , 2010). We mentioned this in Immunohistochemistry Section of our Methods.

In this study produce all raw data related to: type of TNBC (Basal like and Non Basal-like), subtype of cancer, expression of SOX2, P63 and CK 5/6 including staining intensity, distribution of the positively cells and immunoreactive score.

Reference:

Thike AA, Cheok PY, Jara-Lazaro AR, et al. Triple-negative breast cancer: clinicopathological characteristics and relationship with basal-like breast cancer. Mod Pathol. 2010;23(1):123-133.

Livasy CA, Karaca G, Nanda R, et al. Phenotypic evaluation of the basal-like subtype of invasive breast carcinoma. Mod Pathol 2006;19:264-271

Nielsen TO, Hsu FD, Jensen K, et al. Immunohistochemical and clinical characterization of the basal-like subtype of invasive breast carcinoma Clin Cancer Res, 2004;10:5367-5374 Rakha EA, El-Sayed ME, Green AR, et al. Breast carcinoma with basal differentiation: a proposal for pathology definition based on basal cytokeratin expression. Histopathology. 2007 Mar;50(4):434-8.

Sasa M, Bando Y, Takahashi M, et al. Screening for basal marker expression is necessary for decision of therapeutic strategy for triple-negative breast cancer. J Surg Oncol, 2008; 97: 3034

Competing Interests: There is no competing of interest 
Reviewer Report 12 October 2017

https://doi.org/10.5256/f1000research.13722.r26921

(C) 2017 Widodo I. This is an open access peer review report distributed under the terms of the Creative Commons Attribution License, which permits unrestricted use, distribution, and reproduction in any medium, provided the original work is properly cited.

\section{Irianiwati Widodo}

Department of Anatomical Pathology, Faculty of Medicine, Gadjah Mada University, Yogyakarta, Indonesia

\section{Introduction:}

Do not explain the epidemiology of breast cancer too long, but explain more detail about TNBC and its subtypes (Basal-like and non basal-like), such as differences in histological type, behaviour, prognosis, treatment etc. So, the role of p63 and SOX2 on TNBC becomes clearer.

\section{Method:}

Statistical analysis predictive diagnostic value of cytoplasmic p63 expression of basal-like and non basal-like TNBC, as far as I know there should be also negative p63 expression. Therefore I suggest to ask a qualified statistician.

\section{Discussion:}

Explain the importance of negative correlation between p63 expression and metaplastic carcinoma. Compare with previous studies.

\section{Conclusion:}

Mention also other important results of this study such as:

- The frequency of non basal-like is higher than basal-like.

The most common histological type of TNBC is metaplastic carcinoma.

Negative correlation between p63 expression and metaplastic carcinoma

SOX2 expression in TNBC, even there is no stattistically significant

Is the work clearly and accurately presented and does it cite the current literature? Partly

Is the study design appropriate and is the work technically sound?

Yes

Are sufficient details of methods and analysis provided to allow replication by others? Yes

If applicable, is the statistical analysis and its interpretation appropriate? 


\section{I cannot comment. A qualified statistician is required.}

Are all the source data underlying the results available to ensure full reproducibility? Partly

Are the conclusions drawn adequately supported by the results? Partly

Competing Interests: No competing interests were disclosed.

Reviewer Expertise: I am a pathologist with major interest in breast cancer

I confirm that I have read this submission and believe that I have an appropriate level of expertise to confirm that it is of an acceptable scientific standard, however I have significant reservations, as outlined above.

Author Response 25 Nov 2017

Harapan Harapan, Syiah Kuala University, Banda Aceh, Indonesia

Thank you for comments and suggestion. We have deleted some sentences related to the general introduction of breast cancer and added specific information related to TNBC. We would like to confirm that predictive diagnostic analysis in this study was conducted using qualified statistician. There is no evidence to support the importance of the negative correlation between immunoexpression of P63 cytoplasm and immunoexpression SOX2 nucleus in metaplastic carcinoma, and therefore we are unable to discuss this finding in depth. In conclusion section, we have added some additional principal finding as suggested by the reviewer.

Competing Interests: No competing interests were disclosed. 
The benefits of publishing with F1000Research:

- Your article is published within days, with no editorial bias

- You can publish traditional articles, null/negative results, case reports, data notes and more

- The peer review process is transparent and collaborative

- Your article is indexed in PubMed after passing peer review

- Dedicated customer support at every stage

For pre-submission enquiries, contact research@f1000.com 